\title{
Implementasi Model Pembelajaran Tutor Sebaya dalam Kelompok Kecil untuk Meningkatkan Hasil Belajar Siswa dalam Menyelesaikan Soal Cerita di SD Negeri 37 Ampenan Kota Mataram
}

\author{
Ni Ketut Sariani \\ Sekolah Dasar Negeri 37 Ampenan, Kota Mataram - Provinsi NTB \\ *Corresponding Author. Email: niketutsariani@gmail.com
}

\begin{abstract}
The purpose of this study was to describe the implementation of peer tutoring learning models in small groups to improve student learning outcomes in solving story problems. This research method uses classroom action research which is carried out in three cycles. Each cycle has four stages, namely planning, implementation, observation and reflection. The subjects of the research were the sixth graders of SD Negeri 37 Ampenan which consisted of 19 students. The instruments used are observation and tests, while the data analysis technique uses descriptive analysis. The result of this research is through peer tutor learning model in small groups, students' skills in solving story problems show good progress which has an impact on increasing student learning outcomes. Based on this study, the learning outcomes obtained by students on the subject of reading pictures or scaled plans increased the average value to around 8.11 .
\end{abstract}

\begin{abstract}
Abstrak: Tujuan penelitian ini adalah mendeskripsikan implementasi model pembelajaran tutor sebaya dalam kelompok kecil untuk meningkatkan hasil belajar siswa dalam menyelesaikan soal cerita. Metode penelitian ini menggunakan penelitian tindakan kelas yang dilakukan dalam tiga siklus. Setiap siklus terdapat empat tahapan yaitu perencanaan, pelaksanaan, pengamatan dan refleksi.Subjekpenelitian adalah seswa kelas VI SD Negeri 37 Ampenan yang terdiri dari 19 siswa. Instrumen yang digunakan yakni observasi dan tes sedangkan teknik analisis datanya menggunakan ananlisis deskriptif. Hasil dari penelitian ini adalah melalui model pembelajaran tutor sebaya dalam kelompok kecil, ketrampilan siswa dalam menyelesaikan soal cerita menunjukkan kemajuan yang cukup baik yang berdampak pada peningkatan hasil belajar siswa. Berdasarkan penelitian ini bahwa hasil belajar yang diperoleh siswa pada pokok bahasan membaca gambar atau denah berskala nilai rata-ratanya meningkat menjadi berkisar 8,11.
\end{abstract}

\section{Article History}

Received: 16-08-2021

Revised: 29-08-2021

Accepted: 16-09-2021

Published: 05-10-2021

\section{Key Words:}

Peer Tutoring Model, Learning Outcomes, Learning Activities.

\section{Sejarah Artikel}

Diterima: 16-08-2021

Direvisi: 29-08-2021

Disetujui: 16-09-2021

Diterbitkan: 05-10-2021

\section{Kata Kunci:}

Pembelajaran Tutor Sebaya, Hasil Belajar, Aktivitas Belajar.

How to Cite: Sariani, N. (2021). Implementasi Model Pembelajaran Tutor Sebaya dalam Kelompok Kecil untuk Meningkatkan Hasil Belajar Siswa dalam Menyelesaikan Soal Cerita di SD Negeri 37 Ampenan Kota Mataram. Jurnal Paedagogy, 8(4), 529-533. doi:https://doi.org/10.33394/jp.v8i4.4148

\section{Pendahuluan}

Membaca merupakan salah satu aktivitas yang bisa dilakukan oleh setiap orang, dimana, dan kapan pun dengan objek yang berbeda-beda (Pujiastutik, 2021; Harni, 2020). Membaca merupakan kebutuhan yang sangat penting bagi para siswa, sehingga perlu adanya usaha-usaha untuk mengajak siswa mempunyai kebiasaan dan kesenangan dalam membaca (Wahyuningsih, 2021; Kandupi, 2021). Pemahaman membaca merupakan salah satu keterampilan bahasa yang diajarkan di sekolah (Sumaryani, 2015; Muhtasim, 2020). Keterampilan membaca pada umumnya diperoleh dengan cara mempelajarinya di sekolah.

Kenyataan yang ada pada saat ini, masih banyak siswa sekolah dasar yang belum memiliki keterampilan membaca gambar atau denah berskala. Masih banyak juga siswa 
yang belum memahami cara menyelesaikan soal-soal cerita yang berhubungan dengan satuan panjang dan luas pada denah berskala. Hal ini dapat dilihat setiap kali siswa diberi soal tentang denah berskala, sebagian siswa masih mengalami kesulitan. Kemauan dan kemampuan siswa dalam menyelesaikan soal matematika tidaklah menyenangkan bagi guru. Seringkali semua soal matematika dianggap sulit baginya. Maka minat siswa perlu dibangkitkan dalam proses pembelajaran matematika dengan variasi belajar yangmenarik, agar nantinya siswa dapat menyelesaikan soal dengan benar. Siswa diajak belajar di luar kelas untuk dikenalkan pada lingkungan sekitar sebagai obyek pembelajaran. Misalnya siswa diberi tugas melalui kelompok-kelompok kecilnya untuk mengukur halaman sekolah. Dengan dipandu tutor sebayanya, kemudian siswa diharapkan mampu menggambar halaman sekolah dengan denah berskala. Siswa juga dituntut untuk bisa menyelesaikan soal-soal cerita yang berhubungan dengan satuan panjang dan luas, sesuai dengan langkah-langkah menyelesaikan soal cerita yang benar.

Model pembelajaran tutor sebaya merupakan model pembelajaran matematika yang yang memberikan kesempatan yang luas kepada siswa untuk aktif belajar (Mahsup et al., 2020). Dapat juga dikatakan model-model tersebut untuk mengupayakan agar pembelajaran yang terpusat pada dosen berubah menjadi terpusat kepada mahasiswa (Ramadhan, Solehudin, \& Sabri, 2019). Selain itu model tutor sebaya lebih efektif daripada model pembelajaran langsung untuk meningkatkan kemampuan pemecahan masalah (Rohmah, 2019).

Proses pembelajaran matematika di SDN 37 Ampenan pada pokok bahasan tersebut selama ini belum memperoleh hasil yang memuaskan, rata-rata berkisar 5,8. Nilai tersebut perlu ditingkatkan melalui penerapan atau praktik langsung pada bendabenda konkret dan siswa sering diberi latihan soal-soal cerita yang berhubungan dengan kehidupan sehari-hari. Siswa diberi cara atau langkah-langkah menyelesaikan soal cerita dengan benar. Serta diberi pengertian bahwa antara luas pada denah berskala, berbeda dengan luas sebenarnya.

Sehubungan dengan hal tersebut, dari sekian banyak soal-soal latihan yang diberikan guru pada bagian ini masih banyak siswa yang belum memahami dan mengalami kesulitan untuk menghitung luas bangun pada denah dengan bangun sebenarnya, terutama dalam menyelesaikan soal cerita pada denah berskala. Maka penting untuk terus mencari cara-cara yang baik dan benar dalam menyelesaikan soal cerita. Dengan demikian, nantinya siswa benar-benar memahami cara menyelesaikan soal cerita dengan benar, yakni dari apa yang diketahui, apa yang ditanyakan dan apa jawaban soal tersebut, yang akhirnya siswa mampu menuliskan hasil akhir soal tersebut. Menurut Kereng (2003) keberhasilan anak dalam belajar sangat dipengaruhi beberapa faktor seperti guru, alat atau fasilitas, sarana dan prasarana pendidikan, juga lingkungan sekitar, meskipun sifatnya hanya sebagai pendukung atau penunjang dalam pengembangan potensi yang dimiliki oleh siswa yang bersangkutan. Sedangkan faktor yang paling menentukan adalah kemampuan dan kemauan siswa itu sendiri.

Adapun penelitian ini bertujuan mendeskripsikan implementasi model pembelajaran tutor sebaya dalam kelompok kecil untuk meningkatkan hasil belajar matematika siswa dalam menyelesaikan soal cerita.

\section{Metode Penelitian}

Penelitian ini menggunakan penelitian tindakan kelas yang dilakukan dalam tiga siklus. Setiap siklus ada empat tahapan yaitu perencanaan, tindakan, pengamatan, dan 
refleksi. Subyek yang diteliti adalah siswa kelas VI SDN 37 Ampenan Kota Mataram, dengan jumlah 19 siswa yang terdiri dari 8 siswa laki-laki dan 11 siswa perempuan. Sumber data dalam penelitian ini adalah hasil pengamatan dari teman sejawat yang membantu sebagai observer dan hasil tes tertulis siswa. Teknik analisis data yang digunakan adalah analisis deskriptif. Tolok ukur keberhasilan dalam penelitian ini adalah apabila hasil belajar siswa pada pokok bahasan membaca gambar atau denah berskala dalam menyelesaikan soal cerita melalui model pembelajaran tutor sebaya dalam kelompok kecil mencapai nilai rata-rata minimal 7,5, dengan ketuntasan kelas minimal $75 \%$.

\section{Hasil Penelitian dan Pembahasan}

Pada siklus I disampaikan materi tentang cara membaca gambar atau denah berskala yang dikaitkan dengan kehidupan sehari-hari. Terlebih dahulu siswa diingatkan kembali tentang satuan ukuran panjang dan satuan ukuran luas. Namun karena keterbatasan siswa dalam memahami konsep tentang satuan ukuran panjang dan luas. Sehingga pada saat pembelajaran berlangsung banyak siswa yang masih mengalami kesulitan untuk menerapkan satuan ukuran panjang dan satuan luas pada materi membaca gambar atau denah berskala (perbandingan skala). Respon siswa masih kurang, belum menunjukkan adanya minat terhadap materi tersebut. Sehingga hasil yang diperoleh masi sangat kurang, masih di bawah 50\%. Diterapkannya model pembelajaran tutor sebaya dalam kelompok kecil, yaitu dengan memanfaatkan anak-anak pandai diantara kelompoknya untukmemandu dalam menyelesaikan tugas, serta membawa siswa untuk mempelajarimateri dengan benda-benda konkret sebagai objek pembelajaran. Anak dibawa ke luar kelas untuk mengukur luas halaman sekolah dan menggambarkannya dalambentuk gambar atau denah berskala.

Berdasarkan hasil tes yang diperoleh pada siklus I terdapat siswa 11 siswa yang mendapat nilai kurang dari 6,5, rata-rata nilainya 6,32. Sedangkan ketuntansan belajarnya baru mencapai $42 \%$, kenyataan itu menunjukkan hasil pembejaran masih sangat rendah. Dilihat dari hasil tes 8 siswa yang mendapat nilai rendah, hal ini disebabkan mereka belum memahami benar cara menyelesaikan soal cerita tentang membaca gambar atau denah berskala. Di samping itu kehidupan dunia pendidikan di lingkungan tempat tinggal mereka masih membutuhkan orang-orang yang mampu mendorong agar mereka sadar akan manfaat pendidikan yang sebenarnya dan lebih maju.

Sebagai perbaikan pada pelaksanakan siklus I adalah siklus II, pada pelaksanaan siklus II disampaikan materi mengenai cara memecahkan soal cerita tentang membaca gambar atau denah berskala dan cara menafsirkan hasil dari pemecahan soal cerita tentang membaca gambar atau denah berskala. Dikarenakan nilai yang dihasilkan pada siklus I masih ditemui siswa yang mendapat nilai kurang dan kesulitan dalam memahami materi pelajaran. Dengan demikian pelaksanakan pembelajaran pada siklus II, ditekankan pada langkah-langkah menyelesaikan soal cerita tentang membaca gambar atau denah berskala dengan benar. Sehingga diharapkan siswa akan lebih materi pelajaran, serta lebih mudahmengerjakan tes akhir pembelajaran, dengan nilai yang lebih baik.

Pada pelaksanakan siklus II, terdapat 7 siswa yang mendapat nilai kurang dari 6,5, sedangkan yang mendapat nilai lebih dari 6,5 adalah 12 siswa. Tingkat ketuntasan yang diperoleh sudah mencapai 63\%. Sedangkan rata-rata nilai yang diperoleh 7,26. Dengan 
demikian tingkat keberhasilan siswa sudah cukup meningkat. Oleh karena itu pelaksanakan penelitian tindakan dan perbaikan padasiklus III.

Pelaksanaan perbaikan pada siklus III disampaikan materi cara menghitung luas sebenarnya suatu bidang datar pada gambar atau denah berskala dan cara menghitung luas sebenarnya suatu daerah atau kota pada peta berskala. Pelaksanakan proses pembelajaran pada siklus II sudah cukup kondusif, siswa sudah lebih memahami materi pelajaran yang diberikan guru. Dikarenakan sebelum proses pembelajaran berlangsung siswa telah diberi perbaikan bagi yangbernilai kurang, sedangkan yang bernilai lebih diberi pengayaan. Sedangkan untuk lebih menguasai materi pelajaran, diadakan apersepsi sebagai pengulangan materi sebelnya. Dengan demikian pelaksanaan pembelajaran pada sklus III ini sebagianbesar siswa sudah memahami materi yang diberikan guru

Pada pelaksanaan siklus III, tinggal 4 siswa yang memperoleh nilai kurang dari 6,5, sedangkan 15 siswa memperoleh nilai lebih dari 6,5, rata-rata nilai yang diperoleh dalam siklus III adalah 8,11, dan tingkat ketuntasan yang diperoleh telahmencapai $79 \%$. Sehingga keberhasilan siswa dalam proses pembelajaran dengan model pembelajaran tutor sebaya dalam kelompok kecil dalam pokok bahasan menyelesaikan soal cerita tentang membaca gambar atau denah berskala telah mencapai ketuntasan. Dengan demikian, hipotesis tindakan penelitian ini dapat diterima. Hasil penelitian ini sejalan dengan penelitian Pujiastutik (2021), Harni (2020), Ramadhan, R., Solehudin, A., \& Sabri, S. (2019), Rohmah (2019) yang menjelaskan bahwa pembelajaran tuor sebaya memiliki dampak terhadap peningkatan motivasi dan hasil belajar siswa.

\section{Kesimpulan}

Berdasarkan hasil penelitian inin dapat disimpulkan bahwa melalui model pembelajaran tutor sebaya dalam kelompok kecil, kemampuan siswa dalam mengemukakan pendapat dan bekeja sama dalam setiap kelompoknya dapat ditingkatkan. Selain itu, peran tutor sebaya merupakan teman bekerja sekaligus teman belajar sehingga dapat menambah keberanian siswa dalam bertanya, dan mengerjakan tugas guru di depan kelas. Serta ketrampilan siswa dalam menyelesaikan soal cerita menunjukkan kemajuan yang cukup baik, sehingga hasil belajar siswa mengalami peningkatan. Berdasarkan penelitian ini bahwa hasil belajar yang diperoleh siswa kelas VI SD Negeri 37 Ampenan pada pokok bahasan membaca gambar atau denah berskala nilai rata-ratanya meningkat menjadi berkisar 8,11 .

\section{Saran}

Saran yang disampaikan yakni; (1) siswa perlu diberi tugas secara individual untuk mempelajari materi, merangkum atau meringkas lalu mendiskusikan dengan tutor sebaya dalam kelompok kecilnya, dengan cara ini diharapkan kemampuan siswa dalam belajar mandirinya akan memingkat dan belajar merupakan kebutuhan siswa. (2) Dalam proses pembelajaran guru disarankan lebih meningkatkan kemampuan profesionalismenya, dengan selalu mengamati siswa didik dalam setiap proses pembelajaran serta menjadi yang penuh dedikasi.

\section{Daftar Pustaka}

Depdiknas. (2004). Matematika - Materi Pelaihan Terintegrasi. Jakarta: Dirgen Pendasmen. 
Harni, H. (2020). Meningkatkan Kemampuan Membaca Melalui Penerapan Pembelajaran Kooperatif Model Jigsaw pada Siswa Kelas IV SDN 2 Uebone. Jurnal Paedagogy, 7(2), 108-114. doi:https://doi.org/10.33394/jp.v7i2.2503

Kandupi, A. (2021). Upaya Meningkatkan Motivasi Dan Hasil Belajar Siswa pada Materi Menentukan Ide Pokok Paragraf dengan Teknik Membaca Intensif di SD Negeri Bambalo. Jurnal Paedagogy, 8(2), 241-255. doi:https://doi.org/10.33394/jp.v8i2.3482

Kereng, Achmad. (2003). Tenaga Kependidikan Profesional Menghadapi Tantangan. Jakarta: Suara Guru 7-9.

Hamalik. (2001). Proses Belajar Mengajar. Jakarta: PT. Bumi Aksara.

Mahsup, M., Ibrahim, I., Muhardini, S., Nurjannah, N., \& Fitriani, E. (2020). Peningkatan Hasil Belajar Mahasiswa Melalui Model Pembelajaran Tutor Sebaya. Jurnal Kependidikan: Jurnal Hasil Penelitian dan Kajian Kepustakaan di Bidang Pendidikan, Pengajaran dan Pembelajaran, 6(3), 609-616. doi:https://doi.org/10.33394/jk.v6i3.2673

Muhtasim, M. (2020). UPAYA PENERAPAN METODE COOPERATIVE LEARNING TIPE GROUP INVESTIGATION UNTUK MENINGKATKAN HASIL BELAJAR DAN KETERAMPILAN MEMBACA BAHASA INGGRIS SISWA. Jurnal Paedagogy, 2(2), 59-69. doi:https://doi.org/10.33394/jp.v2i2.3049

Pujiastutik, R. (2021). Upaya Meningkatkan Keterampilan Membaca Cepat dengan Menggunakan Metode P2R dan Question pada Siswa SMA Negeri 1 Leces Kabupaten Probolinggo. Jurnal Paedagogy, $8(2), \quad$ 217-225. doi:https://doi.org/10.33394/jp.v8i2.3506

Ramadhan, R., Solehudin, A., \& Sabri, S. (2019). Pengaruh Metode Pembelajaran Tutor Sebaya Terhadap Hasil Belajar Siswa Pada Mata Pelajaran Teknologi Mekanik di SMK. Journal of Mechanical Engineering Education, 5(2), 242. https://doi.org/10.17509/jmee.v5i2.15194

Rohmah, Z. (2019). Penerapan Pembelajaran Matematika melalui Model Tutor Sebaya dengan Pendekatan Saintifik sebagai Upaya Meningkatkan Pemahaman Konsep dan Motivasi Belajar Siswa di Kelas Inklusif. Suska Journal of Mathematics Education, 5(2), 149. https://doi.org/10.24014/sjme.v5i2.8171

Sumaryani, L. (2015). Teaching Reading Strategies for Students at FPBS IKIP Mataram. Jurnal Kependidikan: Jurnal Hasil Penelitian dan Kajian Kepustakaan di Bidang Pendidikan, Pengajaran dan Pembelajaran, 1(2). doi:https://doi.org/10.33394/jk.v1i2.419

Suyitno, Amin. 2004. Dasar-dasar dan Proses Pembelajaran Matemaika I. Bahan Ajar Program 11 Pendidikan Matematika Konsrentrasi PendidikanDasar. Semarang: UNNES.

Wahyuningsih, L. (2021). Meningkatkan Kemampuan Reading Comprehension Siswa SMA Negeri 1 Kebomas Melalui Extensive Reading. Jurnal Paedagogy, 8(1), 112-116. doi:https://doi.org/10.33394/jp.v8i1.3325 